\title{
MINAT BERWIRAUSAHA DITINJAU DARI FAKTOR INTERNAL MAHASISWA PROGRAM STUDI PENDIDIKAN TEKNOLOGI INFORMASI DAN KOMPUTER IKIP PGRI PONTIANAK
}

\author{
Erni Fatmawati $^{1}$, Vindo Feladi ${ }^{2}$ \\ ${ }^{1,2}$ IKIP PGRI Pontianak \\ Email korespondensi : ernifatmawati@gmail.com
}

\begin{abstract}
Abstrak
Tujuan penelitian ini adalah untuk melihat minat berwirausaha ditinjau dari faktor internal mahasiswa Program Studi Pendidikan TIK IKIP PGRI Pontianak. Metode penelitian yang digunakan yaitu metode deskriptif dengan bentuk penelitian survei. Proses yang dilakukan dengan mengidentifikasi, membatasi dan merumuskan, menentukan tujuan dan manfaat, melakukan studi pustaka, menentukan kerangka berpikir, dan hipotesis, mendesain metode, mengumpulkan, mengorganisasikan, dan menganalisis data serta membuat laporan penelitian. Variabel penelitian yang digunakan dalam penelitian adalah variabel tunggal dengan populasi 110 mahasiswa semester VI Program Studi Pendidikan TIK dan jumlah sampel dengan menggunakan tingkat kesalahan sebesar 5\% sebanyak 84 Mahasiswa. Teknik Pengumpulan Data yang digunakan adalah teknik komunikasi tidak langsung dengan alat pengumpul data berupa angket. Teknik analisis data yang digunakan dalam penelitian adalah teknik analisis deskriptif kuantitatif. Hasil penelitian menunjukkan bahwa mahasiswa Program Studi Pendidikan TIK setelah diukur berdasarkan faktor internal yang terdiri dari sub indikator kepribadian, kemampuan, dan motif berprestasi tidak memiliki minat untuk berwirausaha.
\end{abstract}

10.26418/pipt.2021.18

Kata kunci: Minat, Wirausaha, Faktor Internal

\section{PENDAHULUAN}

Badan Pusat Statistik Provinsi Kalimantan Barat merilis data Tingkat Pengangguran Terbuka (TPT) di Kalimantan Barat. Data tersebut merupakan data SAKERNAS Agustus tahun 2020. Pada data yang dirilis tersebut dapat dilihat bahwa jumlah pengangguran di Kota Pontianak mengalami peningkatan dari $9,13 \%$ pada tahun 2019 meningkat menjadi 12,36\% pada tahun 2020. Karena itu pemerintah perlu melakukan pemulihan perekonomian.

Pemerintah membuat strategi untuk memulihkan ekonomi masyarakat Kota Pontianak akibat dari pandemi Covid-19 sehingga semua sektor usaha dapat kembali berjalan normal. Upaya percepatan untuk pemulihan ekonomi salah satunya memberikan pelatihan-pelatihan yang dapat mendorong pertumbuhan ekonomi. Selain itu peningkatan kapasitas sumber daya manusia juga menjadi prioritas.

Pengangguran terdiri dari golongan berpendidikan tinggi maupun yang tidak berpendidikan. Pada golongan berpendidikan tinggi yang menjadi pengangguran disebabkan karena belum siap bekerja akibat pola pikir yang masih berorientasi untuk menjadi pegawai negeri maupun pegawai swasta. Hal ini senada dengan ungkapan Ernani (2010) dalam sebuah seminar dimana besarnya keinginan untuk mendapat pekerjaan yang aman dan tidak berani mengambil risiko seperti berwirausaha cenderung dipilih karena tingkat pendidikan yang semakin tinggi.

Pemikiran tentang pekerjaan yang aman dengan tidak memiliki risiko yang besar harus diubah. Perubahan pola pikir ini dapat dimulai sejak mereka masih melaksanakan pendidikan. Salah satunya dengan menanamkan nilai-nilai kewirausahaan sehingga terbentuk karakter dan perilaku bagaimana menjadi seorang pengusaha yang dapat menciptakan lapangan pekerjaan bagi orang lain. Selain itu dapat membantu pemerintah mengurangi angka pengangguran yang semakin bertambah.

Pembentukan karakter, perilaku, dan 
sifat sebagai seorang pengusaha dapat diperoleh melalui pembelajaran baik di lingkungan sekolah maupun perguruan tinggi, masyarakat, maupun lingkungan keluarga. Salah satu contoh yang ada di lingkungan perguruan tinggi pembentukan ini dapat diperoleh melalui mata kuliah kewirausahaan dimana dalam proses pembelajarannya memberikan motivasi dan penjelasan kepada mahasiswa untuk memahami karakter, cara berpikir, dan sikap seorang pengusaha. Selain itu mahasiswa juga dibimbing untuk dapat mengembangkan kreativitas, membuat inovasi baru dari produk-produk yang telah ada bahkan menciptakan sebuah produk baru yang memiliki nilai jual yang tinggi.

Nilai yang diaplikasikan dalam sebuah perilaku yang dapat dijadikan sebagai sumber daya, tenaga penggerak, tujuan, cara, proses dan hasil usaha dapat dimaknai sebagai kewirausahaan (Sanusi 1994). Sedangkan mampu melihat peluang dan berupaya memperoleh hasil dari peluang yang ada merupakan seorang Wirausahawan (entrepreneur) (Bygrave, 1994).

Pembentukan tingkah laku mahasiswa sehingga memiliki jiwa seorang pengusaha diharapkan dapat diaplikasikan dalam kehidupan sehari-hari, baik di lingkungan sekolah, masyarakat, dan keluarga. Sifat-sifat pengusaha yang diharapkan dimiliki oleh mahasiswa setelah mengikuti mata kuliah kewirausahaan yaitu memiliki kepercayaan diri yang tinggi, mau bekerja keras, berpikir kreatif dan memiliki disiplin serta tanggung jawab yang besar.

Pemerintah mencanangkan pada jenjang perguruan tinggi untuk dapat membentuk pola pikir mahasiswa untuk menjadi wirausahawan (entrepreneur) menjadi sebuah trend. Mahasiswa diharapkan tidak lagi menjadi "pencari kerja" tapi mampu menjadi "pencipta kerja". Pilihan hidup yang menjanjikan diharapkan dapat menjadi sebuah pemikiran dari pendidikan entrepreneur (Wijatno, 2009).

Melalui pendidikan entrepreneur, mahasiswa dapat lebih menyukai kegiatan yang menantang untuk mencapai kesuksesan.
Mahasiswa diharapkan berani menghadapi risiko. Keberanian untuk menghadapi risiko yang merupakan nilai kewirausahaan yaitu pengambilan risiko yang nyata dan penuh perhitungan. Mahasiswa akan memperoleh kepuasan jika berhasil melaksanakan tugastugasnya (Kewirausahaan Modul Pembelajaran, 2013:38).

Program-program kewirausahaan yang telah ditetapkan diharapkan dapat menumbuhkan semangat dan mampu dikembangkan oleh Mahasiswa. Bentuk tingkah laku yang mencerminkan sifat seorang pengusaha sebagai perilaku kewirausahaan mahasiswa dapat diterapkan pada kehidupan sehari-hari. Sebagai contoh dalam hal kedisiplinan dimana mahasiswa datang tepat waktu kreatif dalam mengerjakan tugas dan mengumpulkan tugas tepat waktu karena mereka mengetahui dengan pasti risiko yang akan diterima jika mereka tidak disiplin.

Keyakinan terhadap segala bagian dari kelebihan yang ada pada diri sendiri dan dapat diwujudkan dalam tingkah laku merupakan bentuk rasa percaya diri. Dimana dengan kelebihan dan keyakinan yang ada membuat diri merasa mampu untuk dapat mencapai segala tujuan dalam hidup (Hakim, 2002).

Ketertarikan mahasiswa untuk menjalankan usaha dapat dikatakan sebagai minat berwirausaha. Hal ini dapat dilihat dari indikator yang banyak terdapat dalam kajian teori mengenai faktor-faktor yang mempengaruhi minat berwirausaha.

Kurangnya minat mahasiswa untuk menjadi seorang wirausaha dikarenakan anggapan mereka yang masih berpikir perlunya modal yang besar, sulitnya menjadi seorang wirausahawan, takut akan kegagalan yang menyebabkan kebangkrutan dalam menjalani usaha.

Indikator penelitian yang digunakan untuk mengukur minat berwirausaha mahasiswa yaitu ditinjau dari faktor internal yang meliputi kepribadian, kemampuan dan motif berprestasi. 


\section{METODOLOGI}

Metode penelitian yang digunakan adalah penelitian deskriptif dengan pendekatan kuantitatif. Dalam proses penulisan penelitian menggunakan pengukuran, rumus, perhitungan dan data yang berupa angka di dalam pengajuan usulan, proses penelitian, penentuan hipotesis, pelaksanaan di lapangan, analisis data dan penarikan kesimpulan menggunakan pendekatan kuantitatif.

Sedangkan jenis penelitian yang digunakan dalam penelitian ini yaitu survei. Upaya dalam pengumpulan informasi dari objek yang diteliti yang dianggap dapat mewakili populasi tertentu merupakan makna dari penelitian survei. Metode ini mengacu pada rancangan, jawaban sementara, dan teori yang sudah ada sehingga tidak akan memunculkan teori baru. Penelitian survei merupakan penelitian yang memiliki sifat pengecekan terhadap teori yang sudah ada (Mantra, 2001).

Lokasi penelitian merupakan tempat bagi peneliti untuk mengumpulkan informasi yang dibutuhkan sesuai dengan tema penelitian yang dipilih. Adapun lokasi penelitian ini yaitu di Program Studi Pendidikan Teknologi Informasi dan Komputer (TIK) IKIP PGRI Pontianak. Karena peneliti menganggap program studi ini merupakan tempat yang tepat di masa digital dimana lebih berhubungan dengan bisnis berbasis teknologi ataupun kewirausahaan sehingga penelitian ini sangat tepat di laksanakan. Subjek dalam penelitian ini adalah mahasiswa Program Studi Pendidikan TIK IKIP PGRI Pontianak Angkatan 2018.

Fokus penelitian untuk meneliti lebih jauh mengenai analisis minat berwirausaha mahasiswa angkatan 2018 Program Studi Pendidikan TIK IKIP PGRI Pontianak. Yang menjadi populasi dalam penelitian ini adalah mahasiswa angkatan 2018 yang berjumlah 110 orang. Berdasarkan tabel Isaac and Michael dengan tingkat kesalahan 5\%, maka yang menjadi sampel dalam penelitian ini berjumlah 84 orang mahasiswa.

Teknik komunikasi tidak langsung dengan alat pengumpul data berupa angket menjadi teknik pengumpulan data yang dipilih oleh peneliti. Setelah data terkumpul maka teknik analisis data yang digunakan adalah analisis deskriptif.

\section{HASIL DAN PEMBAHASAN}

Hasil

Berdasarkan angket minat berwirausaha yang telah dikumpulkan dan diolah, maka diperoleh data-data yang dapat dijadikan acuan sebagai hasil penelitian. Pernyataan yang ada di analisis berdasarkan banyaknya responden yang sangat setuju, setuju, tidak setuju dan sangat tidak setuju. Kemudian di cari persentase dari masing-masing pernyataan.

Pada indikator faktor internal terdapat tiga sub indikator yang meliputi kepribadian, kemampuan, dan motif berprestasi.

Tabel 1. Respons Mahasiswa pada Sub Indikator Kepribadian

\begin{tabular}{|c|c|c|c|c|c|}
\hline No & Pernyataan & SS & $\mathbf{S}$ & TS & STS \\
\hline 1 & $\begin{array}{l}\text { Saya Memiliki } \\
\text { Kepercayaan Diri yang } \\
\text { Tinggi untuk Mulai } \\
\text { Berwirausaha }\end{array}$ & $7 \%$ & $11 \%$ & $54 \%$ & $28 \%$ \\
\hline 2 & $\begin{array}{lr}\text { Saya Mudah untuk } \\
\text { Menyerah } & \text { jika } \\
\text { Menghadapi Hal yang } \\
\text { Terlalu Sulit }\end{array}$ & $38 \%$ & $30 \%$ & $26 \%$ & $6 \%$ \\
\hline 3 & $\begin{array}{lr}\text { Saya } & \text { Memiliki } \text { Sifat } \\
\text { Berani } & \text { Mengambil } \\
\text { Risiko } & \\
\end{array}$ & $2 \%$ & $27 \%$ & $51 \%$ & $19 \%$ \\
\hline 4 & $\begin{array}{l}\text { Saya Memiliki Tujuan } \\
\text { yang Jelas Terhadap } \\
\text { Apa yang Dilakukan }\end{array}$ & $7 \%$ & $11 \%$ & $45 \%$ & $37 \%$ \\
\hline
\end{tabular}

Dari empat pernyataan yang diberikan dapat terlihat bahwa responden memiliki tingkat kepercayaan diri yang tinggi untuk mulai berwirausaha, hanya menunjukkan persentase sebesar $18 \%$. Tidak mudah menyerah jika menghadapi kesulitan memiliki persentase skor yang rendah sebesar 32\%. Persentase yang menunjukkan keberanian di dalam mengambil risiko juga sangat kecil yaitu hanya sebesar $29 \%$. Sementara mahasiswa yang memiliki tujuan 
jelas terhadap apa yang dilakukan hanya $18 \%$.

Tabel 2. Respons Mahasiswa pada Sub Indikator Kemampuan

\begin{tabular}{|c|c|c|c|c|c|}
\hline No & Pernyataan & SS & $\mathbf{S}$ & TS & STS \\
\hline 1 & $\begin{array}{l}\text { Saya Memiliki } \\
\text { Kemampuan untuk } \\
\text { Mengelola Usaha }\end{array}$ & $6 \%$ & $20 \%$ & $60 \%$ & $14 \%$ \\
\hline 2 & $\begin{array}{lr}\text { Saya } & \text { Memiliki } \\
\text { Kemampuan } & \text { untuk } \\
\text { Menggunakan } & \\
\text { Keuangan Sesuai } \\
\text { Dengan Perencanaan } \\
\text { yang Telah di Buat }\end{array}$ & $5 \%$ & $19 \%$ & $52 \%$ & $24 \%$ \\
\hline 3 & $\begin{array}{l}\text { Saya Mampu } \\
\text { Mengendalikan Usaha } \\
\text { Sesuai Rencana yang } \\
\text { di Buat }\end{array}$ & $1 \%$ & $26 \%$ & $51 \%$ & $21 \%$ \\
\hline 4 & $\begin{array}{lr}\text { Saya } & \text { Memiliki } \\
\text { Kemampuan } & \text { untuk } \\
\text { Memimpin } & \text { Sebuah } \\
\text { Tim Kerja } & \end{array}$ & $6 \%$ & $20 \%$ & $57 \%$ & $17 \%$ \\
\hline
\end{tabular}

Indikator faktor internal pada sub indikator kemampuan menunjukkan bahwa kemampuan mahasiswa untuk mengelola usaha masih rendah hal ini ditunjukkan dengan persentase sebesar $26 \%$. Sementara kemampuan untuk menggunakan keuangan sesuai dengan perencanaan yang telah dibuat hanya menunjukkan persentase sebesar $24 \%$. Kemampuan untuk mengendalikan usaha sesuai perencanaan hanya menunjukkan persentase sebesar 27\%. Dan kemampuan untuk memimpin sebuah tim kerja hanya menunjukkan persentase sebesar $26 \%$.

Tabel 3. Respons Mahasiswa pada Sub Indikator Motif Berprestasi

\begin{tabular}{|c|l|c|c|c|c|}
\hline No & \multicolumn{1}{|c|}{ Pernyataan } & SS & S & TS & STS \\
\hline 1 & $\begin{array}{l}\text { Saya } \\
\text { Memanfaatkan } \\
\text { Setiap Kesempatan } \\
\text { yang Ada Demi } \\
\text { Pengembangan Diri } \\
\text { Saya }\end{array}$ & $6 \%$ & $11 \%$ & $57 \%$ & $26 \%$ \\
\hline 2 & $\begin{array}{l}\text { Saya Meminta } \\
\text { Orang Lain untuk } \\
\text { Memberikan } \\
\text { Tanggapan } \\
\text { Terhadap Hal yang } \\
\text { Saya Lakukan } \\
\text { untuk Mencapai } \\
\text { Suatu Tujuan } \\
\text { Tertentu }\end{array}$ & $12 \%$ & $52 \%$ & $27 \%$ \\
\hline 3 & Saya Optimis untuk & $4 \%$ & $17 \%$ & $51 \%$ & $29 \%$ \\
\hline
\end{tabular}

\begin{tabular}{|c|c|c|c|c|c|}
\hline & $\begin{array}{l}\text { Dapat Mencapai } \\
\text { Keberhasilan } \\
\text { Dalam Situasi } \\
\text { Apapun }\end{array}$ & & & & \\
\hline 4 & $\begin{array}{lr}\text { Bila } & \text { Saya } \\
\text { Mengalami } & \\
\text { Kesulitan } & \text { Dalam } \\
\text { Mengerjakan } & \\
\text { Sesuatu, } & \text { Saya } \\
\text { Lebih } & \text { Suka } \\
\text { Berusaha } & \text { Keras } \\
\text { untuk } & \\
\text { Menyelesaikannya } \\
\text { Daripada } \quad \text { Beralih } \\
\text { Padar Pekerjaan } \\
\text { Lain }\end{array}$ & $4 \%$ & $20 \%$ & $45 \%$ & $31 \%$ \\
\hline
\end{tabular}

Sub indikator dari faktor internal berikutnya adalah motif berprestasi. Pada sub indikator ini dapat dilihat mahasiswa yang memanfaatkan setiap kesempatan yang ada demi pengembangan diri hanya menunjukkan persentase sebesar $17 \%$. Meminta orang lain untuk memberikan tanggapan terhadap hal yang dilakukan untuk mencapai suatu tujuan tertentu menunjukkan persentase sebesar $20 \%$. Memiliki sikap optimis untuk dapat mencapai keberhasilan dalam situasi apapun hanya menunjukkan persentase sebesar $21 \%$. Dan berusaha keras untuk menyelesaikan kesulitan yang dihadapi ketika mengerjakan sesuatu hanya menunjukkan persentase sebesar $24 \%$.

\section{Pembahasan}

Mahasiswa berdasarkan hasil analisis angket yang telah disebar pada sub indikator kepribadian menunjukkan bahwa responden yang tidak memiliki tingkat kepercayaan diri untuk mulai berwirausaha, menunjukkan persentase sebesar $82 \%$. Mudah menyerah jika menghadapi kesulitan memiliki persentase skor yang tinggi sebesar $68 \%$. Persentase yang menunjukkan ketidakberanian di dalam mengambil risiko sangat besar yaitu sebesar $71 \%$. Sementara mahasiswa yang tidak memiliki tujuan jelas terhadap apa yang dilakukan sebesar $82 \%$. Dari hasil ini dapat disimpulkan bahwa mahasiswa tidak memiliki kepribadian untuk menjadi seorang wirausaha. 
Indikator faktor internal pada sub indikator kemampuan menunjukkan bahwa mahasiswa tidak memiliki kemampuan untuk mengelola usaha sangat tinggi dengan persentase sebesar $74 \%$. Sementara ketidakmampuan untuk menggunakan keuangan sesuai dengan perencanaan yang telah dibuat menunjukkan persentase sebesar 76\%. Ketidakmampuan untuk mengendalikan usaha sesuai perencanaan menunjukkan persentase sebesar 73\%. Dan ketidakmampuan untuk memimpin sebuah tim kerja menunjukkan persentase sebesar 74\%. Dengan demikian dapat disimpulkan bahwa mahasiswa tidak memiliki kemampuan untuk mengelola, menggunakan dan mengendalikan usaha.

Faktor internal pada sub indikator motif berprestasi menunjukkan bahwa mahasiswa yang tidak memanfaatkan setiap kesempatan yang ada demi pengembangan diri menunjukkan persentase sebesar $83 \%$. Tidak berani meminta orang lain untuk memberikan tanggapan terhadap hal yang dilakukan untuk mencapai suatu tujuan tertentu menunjukkan persentase sebesar $80 \%$. Tidak memiliki sikap optimis untuk dapat mencapai keberhasilan dalam situasi apapun menunjukkan persentase sebesar 79\%. Dan tidak mau berusaha keras untuk menyelesaikan kesulitan yang dihadapi ketika mengerjakan sesuatu menunjukkan persentase sebesar $76 \%$. Dengan demikian dapat disimpulkan bahwa secara motif berprestasi menunjukkan bahwa mahasiswa tidak memiliki motif berprestasi dalam berwirausaha.

\section{KESIMPULAN}

Dari pembahasan yang telah dipaparkan terlihat bahwa secara internal sebagian besar mahasiswa tidak memiliki kepribadian, kemampuan, dan motif berprestasi untuk berwirausaha. Dengan demikian dapat disimpulkan bahwa mahasiswa Program Studi Pendidikan TIK setelah diukur berdasarkan faktor internal yang terdiri dari sub indikator kepribadian, kemampuan dan motif berprestasi tidak memiliki minat untuk berwirausaha.

\section{UCAPAN TERIMA KASIH}

Penelitian ini dapat terselesaikan dengan baik karena adanya bantuan dari pihak-pihak yang terlibat. Untuk itu peneliti mengucapkan terima kasih yang sebesarbesarnya kepada:

1. Lembaga Penelitian dan Pengabdian Pada Masyarakat IKIP PGRI Pontianak

2. Program Studi Pendidikan Teknologi Informasi dan Komputer IKIP PGRI Pontianak

3. Panitia penyelenggara Seminar Nasional PIPT VI 2021 Universitas Tanjungpura Pontianak

\section{DAFTAR PUSTAKA}

Alma B. (2014). Manajemen Pemasaran dan Pemasaran Jasa. Bandung: CV Alfabeta.

Bygrave William D. (1994). The Portable $M B A$ in Entrepreneurship. John Willeys\&Son Inc. New York

Ernani H. (2010). Analisis Kulaitas Pelayanan dan Pengaruhnya Terhadap Loyalitas Pelanggan (Studi Kasus pada PT. Pos Indonesia (Persero) Kantor Pos Lawang). Jurnal Manajemen Pemasaran Modern 2 (2).

Hakim Thursan. (2002). Mengatasi Rasa Tidak Percaya Diri. Jakarta: Puspa Swara.

Sanusi Ahmad. (1994). Menelaah Potensi Perguruan Tinggi untuk Membina Program Kewirausahaan dan Mengantar Pewirausaha Muda, Makalah Seminar. Kopma IKIP.

Wijatno S. (2009), Pengantar Entrepreneurship, Jakarta: PT Gramedia Widiasarana Indonesia. 
Bidang Ilmu Pengetahuan Sosial 